situation "dire and the future of labor environmentalism uncertain" (131). In this context, it is especially important that Making a Living has as wide readership, both in the academy and in social movements.

Julie Sze

University of California, Davis

\title{
Paul Kopas, Taking the Air: Ideas and Change in Canada's National Parks (Vancouver: University of British Columbia Press, 2007).
}

University of British Columbia political scientist Paul Kopas has taken on a difficult task-making sense of national parks policy since the mid-1950s. Serving as an historian in the Prairie and Northern Regional Office of Parks Canada in the early 1980s, I often wondered about the federal government's policy decisions. In fact, I was just figuring out how things apparently worked when I traded one bureaucracy for another by moving to a university. But I have always remained interested in national parks policy and history and that's why I read the Kopas book with such interest.

Taking the Air seeks to explain the development and evolution of national parks policy by examining the dominant contextualizing policy ideas during the latter half of the twentieth century. Kopas argues that these shifting or new ideas, although not usually stated in policy, have shaped and influenced national parks decision-making and legislation. The contextualizing idea of the 1970s, for example, was that the public should play a key role in policy formation and that such participation was considered both necessary and crucial; hence, any new park developments from 1970 to 1979, according to Kopas, were largely initiated by public participation (such as the review of management plans) and not by the bureaucracy.

Using contextualizing ideas as his analytical model, Kopas tries to identify the key concepts and contributing factors that have determined national parks policy since the end of the Second World War. He looks first at the early history of national parks in Canada and how the establishment of Banff in 1885, and six other parks in western Canada before 1900, had more to do with national development than with environmental protection. In fact, Kopas notes that even though the 1930 National Parks Act was unprecedented for its time, because of its ecological provisions, national parks in the first half of the twentieth century had a kind of split identity - existing as both nature preserves and recreational playgrounds. He also maintains that the environmental features of the act were never effectively implemented because of depression and war and that it fell to post-war planners to bring national parks in line with the 1930 legislation.

The better part of Taking the Air is devoted to the period from 1955 to the early twenty-first century and how the parks branch, then public participation, 
followed by organized interests, and finally, reinvented government, shaped national parks policy. Sometimes, it was the bureaucracy that introduced change from within; in other periods, it was outside forces that pushed the agenda. The overall thrust, however, was a movement towards 'ecological integrity' as the defining feature of Canada's national parks. Kopas documents, sometimes repetitively, the growing emphasis on the parks' environment by highlighting the adoption of the 1964 National Parks policy statement, the implementation of a system plan in 1970, and the passage of the 1988 National Parks Act. He even suggests towards the end of his study that the creation of the Parks Canada Agency in 1998 meant "that Canada's national parks are, in formal policy, more strongly protected than at any time in their history" (174). Indeed, during recent federal cost-cutting, Parks Canada has been largely spared, something that probably would not have happened if it had been just another program under a department.

But policy is not always mirrored in practice. And even though ecological integrity may be the watchwords today, national parks are still struggling with their split identity as both nature reserves and regional playgrounds. Kopas documents this tension, but largely prefers to focus on examples where development has been trumped by environmental concerns, such as the 1972 federal decision to reject the Village Lake Louise Project. There are other cases, though, where powerful local interests have wielded considerable influence, such as in Prince Albert National Park when the superintendent was silenced and then relocated because she argued that an insect infestation in the Waskesiu townsite should be allowed to take its natural course (Kopas, by the way, incorrectly spells it, Wakasui). It was in this same townsite in the 1970s that portable cabin and shack tents owners successfully stared down the government over its plans to get rid of the residential area. Then, there are those instances where politics, not policy, matter most. Such was the case for Grasslands National Park, which was established in 1989 as a trade-off in exchange for a federal licence to proceed with a controversial dam project in the Saskatchewan Premier's home riding.

Kopas also describes how Aboriginal peoples have become important players in recent national park creation and operation, especially in northern Canada. Where First Nations and Métis were once shooed from their traditional lands to make way for national park designation, new parks now allow for Native presence and in some cases, resource use. What Kopas does not suggest, however, is possibly an even greater role for Aboriginal peoples in future national parks, particularly since any new national parks are more likely to be found in Canada's north where the federal government does not have to deal with provincial governments. Parks like Ivvavik, Aulavik, Tuktut, Nogait, and Sirmlik owe their creation to various northern Aboriginal communities.

The most troubling part of Taking the Air is how the reorganization of the mid-1990s, under the guise of reinvented government, did so much damage to the national parks service. Ironically, these changes took place at the same time 
that ecology was supposed to have precedence in policy decisions. First, there was the questionable transfer of the Parks Branch to the new Department of Canadian Heritage. Then, budgetary constraints devastated employee morale. (Here, interviews with former parks personnel would have been instructive.) Sadly, as Kopas notes, reorganization reached the point where superintendents and other supervisory personnel were not dedicated to one particular park and moved around like migratory animals. In retrospect, it appears that I was lucky to have worked at Parks Canada when I did.

Bill Waiser

University of Saskatchewan

\section{Londa Schiebinger, Plants and Empire: Colonial Bioprospecting in the Atlantic World (Cambridge, MA: Harvard University Press, 2004).}

From the title and cover of Londa Schiebinger's engaging, provocative book, one would never guess that it was about abortion. Not that the title is misleading. Schiebinger provides a fascinating and well researched account of European and Creole botanical explorers in the western hemisphere, their interactions with indigenous experts, and the "linguistic imperialism" of Carl Linnaeus and his followers who imposed European names_-often the names of prominent European botanists or patrons - on American, African, and Asian plants. But her story centers on a plant, commonly known as the pride-of-Barbados, also called the peacock flower (Poinciana pulcherrima L. or Caesalpinia pulcherrima $([\mathrm{L}] \mathrm{Sw})$, the slaves and Indians who used it and other plants as abortifacients, and the reasons why knowledge of its abortifacient properties did not become part of European medical botany.

Medicinal plants were big business in the eighteenth century, and a wide range of travelers sought them out. With the anachronism "bioprospecting" Schiebinger underscores the parallels between their efforts and modern pharmaceutical companies' attempts to find new drugs by exploiting indigenous knowledge. But no Rio Convention protected indigenous peoples' rights to their botanical products and lore in the eighteenth century; if some "biopirates" like NicolasJoseph Thiery de Menonville thought that natives should be compensated for the plants and knowledge he took from them-unless they were subjects of the enemy Spanish-few shared his scruples. Schiebinger introduces readers to a wide range of bioprospectors. She includes heroic "voyager botanists" such as Hans Sloane and Maria Sibylla Merian, on whom earlier historians tended to focus, but she introduces us to "type specimens" of others: mercenary biopirates, Creole naturalists, and traveling botanical assistants, like Jeanne Baret, the assistant and (probably) lover of Philibert Commerson, physician on Bougainville's circumnav- 